\title{
PERANCANGAN SISTEM APLIKASI PELACAKAN PENGIRIMAN PAKET POS BERBASIS WEBSITE CABANG PT. XWZ
}

\section{APPLICATION DESIGN OF POST DELIVERY TRACKING APPLICATION BASED ON WEBSITE BRANCH OF PT. XWZ}

\author{
Iskandar*, Adam Firdaus Muslim \\ * Program Studi Teknik Informatika, Sekolah Tinggi Teknologi Muhammadiyah Cileungsi \\ * Jl. Anggrek No.25, Perum PTSC, Cileungsi, Bogor, Jawa Barat, Indonesia 16820
}

\begin{tabular}{l} 
Informasi Artikel \\
\hline Article History: \\
Submission: 02/05/2021 \\
Revised: $12 / 06 / 2021$ \\
Accepted: 15/06/2021 \\
Kata Kunci: \\
Pelacakan; Rancangan web; \\
Paket. \\
Keywords: \\
Tracking; Web drafts; \\
Packages. \\
* Korespondensi: \\
Iskandar \\
iskandar@sttmcileungsi.ac.id
\end{tabular}

1. PENDAHULUAN.

Perkembangan zaman menuntut adanya pengiriman barang, dari tempat berbeda ke tempat yang diinginkan. Ada banyak masalah yang terjadi di dalam proses itu. Mulai estimasi waktu

\begin{abstract}
Abstrak
Perkembangan teknologi pengiriman surat dan paket, merupakan faktor utama pendorong kemajuan bagi masyarakat dan negara. Kemudahan dalam pengiriman surat dan paket antar pulau dan negara membuat masyarakat semakin maju dan berkembang karena tidak harus datang ke tempat yang mereka ingin tuju, Penelitian ini bertujuan untuk mengusulkan pembaruan rancangan sebuah sistem Website untuk melacak keberadaan paket yang dikirim melalui ekspedisi PT. XYZ. Perancangan Website telah menghasilkan suatu rancangan Website untuk mendukung proses pelacakan paket, alur berjalannya paket, dan berupaya mempercepat proses update status kiriman paket. Pengembangan Perangkat lunak menggunakan metode Agile Framework Scrum dengan menggunakan bahasa pemrograman php dengan framework Codeigniter 4.0. Hasil evaluasi implementasi aplikasi menunjukan performance usability $76.26 \%$, sehingga rata-rata penelusuran memerlukan waktu 15 second, sehingga dapat memperbaharui proses pengiriman dan penelusuran paket menjadi lebih baik.
\end{abstract}

\begin{abstract} factor driving progress for society and the country. The ease of sending letters and packages between islands and countries makes people more advanced and developing because they don't have to come to where they want to go. This study aims to propose an update to the design of a website system to track the existence of packages sent through the expedition of PT. XYZ. Website Design has produced a Website design to support the package tracking process, the flow of the package, and trying to speed up the process of updating the status of package shipments. Software development using the Agile Framework Scrum method using the PHP programming language with the Codeigniter 4.0 framework. The results of the evaluation of the application implementation show usability performance of $76.26 \%$, so that the average search takes 15 seconds so that it can update the sending and tracking process for packets to be better.
\end{abstract}


atau jarak tempuh barang, keamanan barang yang sedang dikirim oleh pengirim, dan lain-lain. Seiring waktu permasalahan ini perlahan diatasi dengan teknologi.

Pengiriman adalah proses pengangkutan barang. Sebagian besar barang dikirim melalui jaringan transportasi. Cargo (barang fisik) yang terutama dilakukan melalui jalan dan rel kereta api di darat, jalur pelayaran di jaringan laut dan maskapai penerbangan di udara. Barang khusus tertentu dapat disampaikan melalui jaringan, seperti pipa untuk barang cair, jaringan listrik untuk tenaga listrik dan jaringan komputer seperti jaringan internet atau siaran untuk informasi elektronik.

Proses pengiriman barang umum dikenal sebagai distribusi. Studi proses yang efektif untuk pengiriman dan disposisi barang dan personil disebut logistik. Perusahaan yang mengkhususkan diri dalam memberikan barang komersial dari titik barang atau penyimpanan ke titik penjualan umumnya dikenal sebagai distributor. Sementara mereka yang berspesialisasi dalam pengiriman barang dari titik penjualan ke konsumen dikenal sebagai jasa pengiriman. Pos, kurir, dan relokasi layanan juga memberikan barang untuk kepentingan komersial dan pribadi. Sedangkan pengertian pengiriman barang atau delivery order dalam buku Kamus Akuntansi Inggris-Indonesia adalah "pesan tertulis kepada penyimpan atau pengangkut untuk menyerahkan"[1].

\section{METODE}

Penelitian ini dilakukan dilakukan di kantor cabang PT. XYZ dalam pengembangan aplikasi ini menggunakan metode Agile, dimana metode agile termasuk pada metode pengembangan terfokus pada kecepatan dan kesederhanaan[2]. Scrum merupakan bagian dari Agile merupakan sebuah framework yang dapat mengatasi suatu masalah yang komplek dan selalu berubah-ubah dan juga framework scrum ini dapat menghasilkan kualitas produk dari perangkat lunak yang sesuai dengan keinginan dari penggunanya[3].

\subsection{Scrum}

Scrum merupakan metode pengembangan perangkat lunak yang diinspirasi dari kekurangan-kekurangan yang ada pada metode waterfall[4]. Dimana metode ini dirancang dengan detail dan terfokus pada bagaimana menyelesaikan proyek perangkat lunak ontime sesuai jadwal dan berkualitas baik. Pada proyek perangkat lunak metode Scrum menekankan bagaimana berkolaborasi dengan baik dan kemampuan untuk beradaptasi dengan perubahanperubahan sesuai dengan kebutuhan pada realisasi prose bisnis.

A. Scrum

Framework scrum merupakan metode agile yang melakukan terobosan-terobosan terhadap kegagalan yang disebabkan metode waterfall.

B. Scrum rules.

Untuk rule dari scrum dimana memiliki tiga peran penting yaitu: Product Owner, Scrum master dan development team.

1) Product owner

Yaitu orang mempunyai visi, otoritas dan waktu luang dalam pengerjaan proyek perangkat lunak. Dimana produk owner ini seorang yang bertanggung jawab untuk mengkomunikasikan terkait visi dan prioritas pada tim pengembangan.

2) Scrum master

Yaitu orang bertindak sebagai fasilitator untuk pemilik produk dan tim pengembang yang terdiri dari pengembang atau developer dan tester (Team penguji software). Scrum 
Master ini tidak mempertanggungjawabkan dalam hal pengelolaan tim. Diman Scrum master itu mempunyai tanggung jawab dalam hal menghilangkan hambatan, membantu kreatif dan produktif serta memantau perkembangan keberhasilan penyelesaian produk perangkat lunak kepada pemilik produk serta juga memberi saran pada pemilik produk mengenai bagaimana memaksimalkan Return On Investment (ROI) pada tim.

3) Scrum development team

Yaitu seseorang yang tergabung dalam tim pengembang software, untuk gambaran metodologi scrum terlihat pada gambar 1.

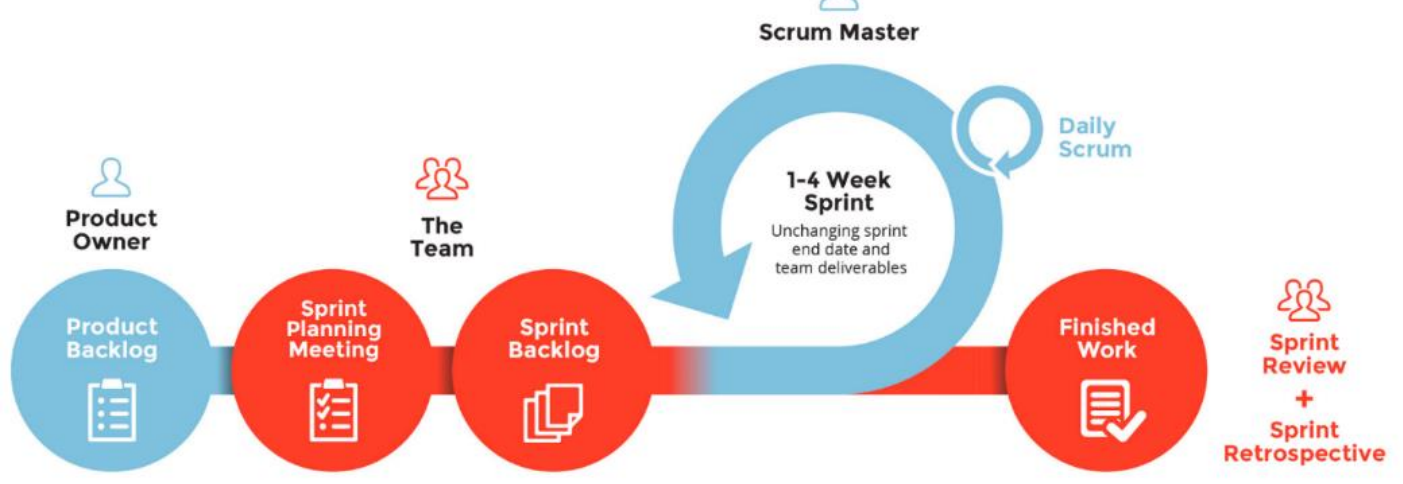

Gambar 1. Scrum methodology[5].

\section{3) Scrum meetings}

Scrum meeting merupakan rapat yang diadakan dalam proses pengembangan perangkat lunak, dimana kegiatan rapat ini disponsori oleh scrum master, dimana Scrum master ini memiliki otoritas dalam pengambilan keputusan dalam setiap kegiatan rapat.

Dalam proses pengembangan perangkat lunak sistem pelacakan pengiriman ini, digunakan metode Agile dengan framework scrum adapun ilustrasi pada gambar 2 .

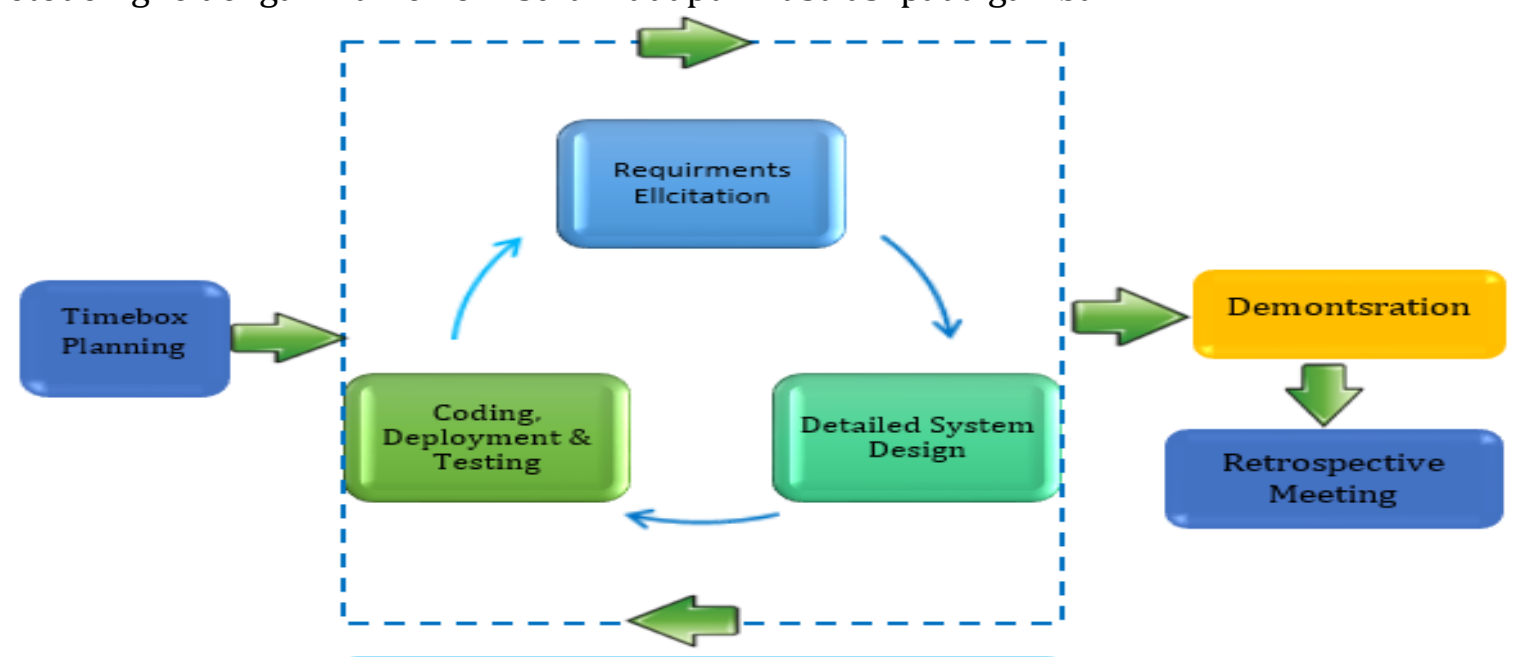

Daily Standup Meeting

Gambar 2. Langkah pengembangan software menggunakan metode agile[6].

1) Timebox planning dimana hal ini membahas tentang perencanaan dalam membangun sistem pelacakan paket pengiriman POS di Cabang XYZ berbasis website dengan melibatkan petugas pengirim paket pos serta Scrum Master, sehingga setiap pengirim paket/barang bisa mengecheck kondisi keberadaan paket yang sedang dikirim. 
2) Daily Stand-Up Meeting dimana hal ini membahas terkait: Requirement Elicitation, Detail System Design, Coding Development dan Testing. Selanjutnya membuat analisis kondisi sistem berjalan dengan menggunakan metode analisis dengan Unified Modelling Language (UML) dimana didalamnya terdapat sistem berjalan dan Use Case Diagram dan melakukan pengkodean sistem pelacakan pengiriman paket dan pengujian sistem pelacakan pengiriman paket pos berbasis website dalam mengetahui paket sudah sampai ke penerima. Perspektif dari pengguna yang telah diterjemahkan pengembang perangkat lunak supaya dapat memperlancar penyelesaian sistem baru.

3) Demonstration, pada proses mengenai penjelasan proses kerja sistem pelacakan paket pos berbasis website.

4) Retrospective Meeting, pada proses ini dilakukan pertemuan yang diinisiator oleh Scrum Master, dimana pada meeting ini dilakukan pembahasan mengenai Sprint yang baru dibuat apakah bisa diubah menjadi sprint selanjutnya yang lebih produktif.

Adapun langkah-langkah menggunakan metode agile dengan framework scrum, dalam pengembangan perangkat lunak, dimana menggambarkan state pada sistem berjalan.

\section{A. Elicitation notes}

Dari hasil pengamatan dan analisis pada sistem berjalan pengiriman paket pos, maka Elicitation Notes berisi tahapan-tahapan yang akan dibuat pada tabel Elicitation Notes seperti pada tabel 1 .

Tabel 1. Elicitation notes sistem pelacakan paket pos

\begin{tabular}{l|l}
\hline \multicolumn{2}{c}{ Elicitation Notes } \\
\hline Nama Sistem & $\begin{array}{l}\text { Sistem Aplikasi Pelacakan Pengiriman Paket Pos Berbasis Website } \\
\text { Cabang PT. Pos XYZ }\end{array}$ \\
\hline Metode & Field Research \\
\hline Sumber & User \\
\hline 1. Pegawai pos mengentri data pengirim paket pos ke komputer \\
\hline
\end{tabular}

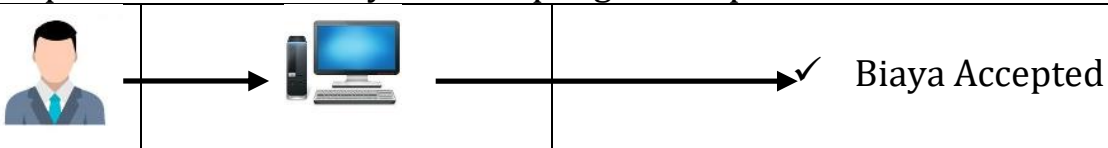

3. Kurir update Status: Accepted by Courier (paket berhasil dikirim oleh kurir)

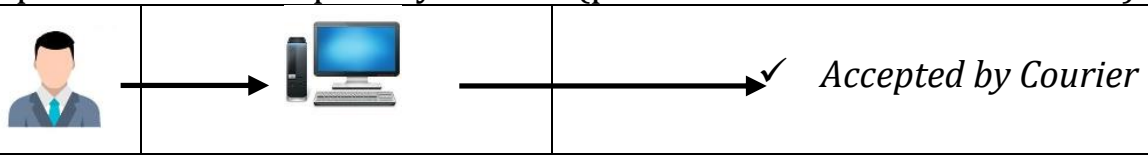

4. Kurir update Status: Collected (dalam proses pengumpulan )

5. Kurir update Status: Shipped (dalam proses pengiriman)

6. Kurir update Status: In-Transit (dalam proses transit)

7. Kurir update Status: Arrived at Destination ( sampai tujuan)

8. Kurir update Status: Ready to Pick Up (siap untuk dijemput paket)

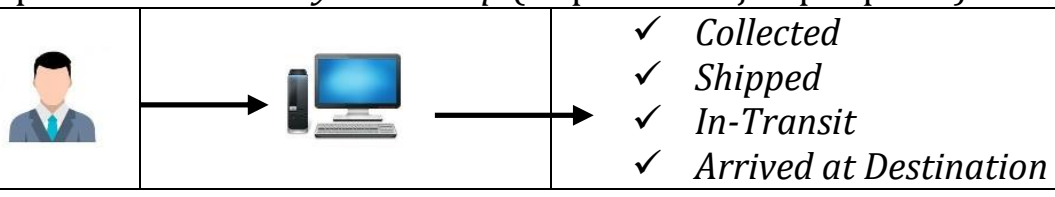




\section{Ready to Pick Up}

9. Pengirim melakukan pelacakan no. resi

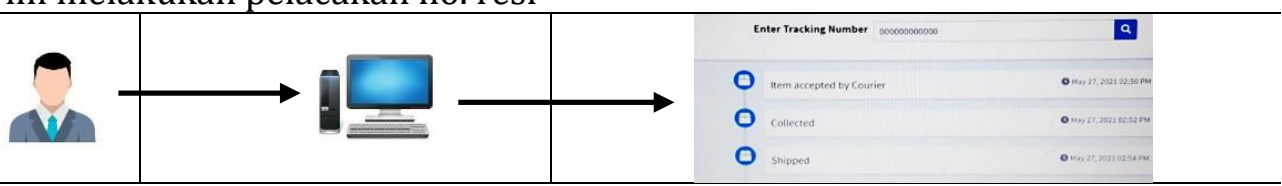

\section{B. Product backlog}

Daftar tahapan dalam backlog adalah seperti pada tabel 2 .

Tabel 2. Product backlog

\begin{tabular}{|c|c|c|c|c|c|c|c|c|c|}
\hline \multirow{2}{*}{ No } & \multirow{2}{*}{ Task Description } & \multirow{2}{*}{ Responsible } & \multirow{2}{*}{ Task Status } & \multicolumn{6}{|c|}{ Day of Sprint } \\
\hline & & & & 1 & 2 & 3 & 4 & 5 & 6 \\
\hline 1 & Login Kurir & Developer 1 & completed & 3 & 3 & 0 & 0 & 0 & 0 \\
\hline 2 & Login Admin & Developer 2 & completed & 3 & 3 & 0 & 0 & 0 & 0 \\
\hline 3 & $\begin{array}{l}\text { Interface } \\
\text { Paket }\end{array}$ & Developer 1 & completed & 0 & 0 & 4 & 5 & 0 & 0 \\
\hline 4 & $\begin{array}{l}\text { Interface update } \\
\text { status paket }\end{array}$ & Developer 2 & complated & 0 & 0 & 5 & 6 & 0 & 0 \\
\hline 5 & $\begin{array}{l}\text { Interface } \\
\text { Paket }\end{array}$ & Developer 1 & complated & 0 & 0 & 0 & 0 & 6 & 7 \\
\hline
\end{tabular}

C. Sprint backLog

Daftar sprint backlog adalah seperti pada tabel 3.

Tabel 3. Sprint backlog

\begin{tabular}{|c|c|c|c|c|c|c|c|c|c|c|}
\hline \multirow{2}{*}{ No } & \multirow{2}{*}{ Backlog Item } & \multirow{2}{*}{ Task } & \multirow{2}{*}{ Responsible } & \multirow{2}{*}{$\begin{array}{l}\text { Initial } \\
\text { Est. }\end{array}$} & \multicolumn{6}{|c|}{ Day of Sprint } \\
\hline & & & & & 1 & 2 & 3 & 4 & 5 & 6 \\
\hline \multirow{4}{*}{1.} & \multirow{4}{*}{$\begin{array}{l}\text { Analisis dan } \\
\text { Perancangan }\end{array}$} & Analisis masalah & $\begin{array}{l}\text { Sistem } \\
\text { analis }\end{array}$ & 1 & 1 & 0 & 0 & 0 & 0 & 0 \\
\hline & & $\begin{array}{l}\text { Analisis } \\
\text { kebutuhan sistem }\end{array}$ & $\begin{array}{l}\text { Sistem } \\
\text { analis }\end{array}$ & 2 & 0 & 1 & 1 & 0 & 0 & 0 \\
\hline & & $\begin{array}{l}\text { Analisis } \\
\text { kebutuhan } \\
\text { perangkat }\end{array}$ & $\begin{array}{l}\text { Sistem } \\
\text { analis }\end{array}$ & 1 & 0 & 0 & 1 & 0 & 0 & 0 \\
\hline & & $\begin{array}{l}\text { Analisis } \\
\text { kebutuhan user }\end{array}$ & $\begin{array}{l}\text { Sistem } \\
\text { analis }\end{array}$ & 3 & 0 & 1 & 1 & 1 & 0 & 0 \\
\hline Spr & nt-1 & & & 7 & 1 & 2 & 3 & 1 & 0 & 0 \\
\hline \multirow{3}{*}{2 . } & \multirow{3}{*}{$\begin{array}{c}\text { Desain } \\
\text { interface \& } \\
\text { Coding }\end{array}$} & Basis data & Developer 1 & 2 & 0 & 0 & 1 & 1 & 0 & 0 \\
\hline & & User interface & Developer 1 & 2 & 0 & 0 & 0 & 1 & 1 & 0 \\
\hline & & Coding & Developer 2 & 5 & 0 & 0 & 2 & 5 & 0 & 0 \\
\hline \multicolumn{2}{|c|}{ Sprint-2 } & & & 9 & 0 & 0 & 3 & 4 & 1 & 0 \\
\hline \multirow{4}{*}{3.} & \multirow{4}{*}{$\begin{array}{l}\text { Implementa } \\
\text { si Sistem }\end{array}$} & Implementasi & Developer 2 & 3 & 0 & 0 & 0 & 1 & 1 & 1 \\
\hline & & Instalasi & Developer 2 & 3 & 0 & 0 & & 1 & 1 & 1 \\
\hline & & User testing & Developer 2 & 4 & 0 & 0 & 0 & 0 & 2 & 2 \\
\hline & & Release & Developer 2 & 2 & 0 & 0 & 0 & 0 & 0 & 2 \\
\hline
\end{tabular}




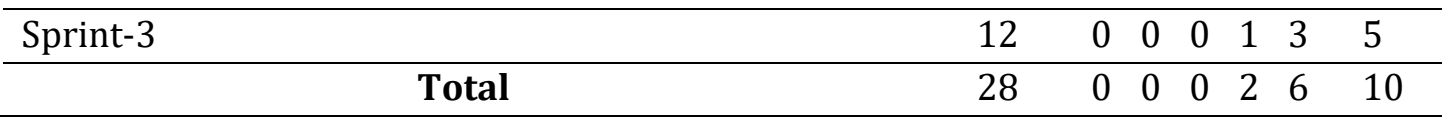

\subsection{Aplikasi sistem pelacak pengiriman}

Aplikasi penelusuran pengiriman paket adalah aplikasi yang membantu petugas pengiriman paket dalam memantau kondisi paket untuk dikirim pada penerima. Dalam perancangannya aplikasi sistem pelacakan pengiriman paket ini dikembangkan menggunakan framework Codeigniter yang bertujuan dalam memudahkan pengorganisasian dalam mengelola tools dan library pemrograman supaya lebih terstruktur sehingga memudahkan dalam proses perbaikan logika program peningkatan keamanan.

\subsection{Framework codeigniter}

Penggunaan framework codeigniter 4 dalam pemrograman berbasis web untuk pelacakan pengiriman paket menggunakan bahasa pemrograman codeigniter dengan untuk tujuan memudahkan dalam pengelolaan modul dan asset dalam membangun sebuah aplikasi berbasis website. Kelebihan framework CI dapat digunakan dalam membangun aplikasi website dengan komposisi yang kompleks karena sudah tersedia pada framework ini karena apa yang dibutuhkan untuk semua class dan modul sudah tersedia sehingga mempermudah programmer dalam membuat aplikasi [7].

\subsection{UML}

Dalam proses analisis dalam pembuatan aplikasi pengiriman paket mengantisipasi pada analisis UML berdasarkan pengertian dari beberapa penelitian sebelumnya terkait pendefinisian Unified Modelling Language(UML)[8],[9],[10] merupakan pemodelan software atau menggambarkan yang dibentuk dari simbol dan diagram. perancangan sistem pada tahapan fase analisis kebutuhan, use case diagram skenario use case, sequence diagram, activity diagram dan perancangan database, spesifikasi database, dan merancang antar muka.

\section{HASIL DAN PEMBAHASAN}

Sebagai perbandingan terkait penelitian yang berhubungan dengan pokok bahasan penelitian dengan penelitian-penelitian sebelumnya dalam rangka rangka sebagai sumber referensi pada penelitian yang sedang berjalan seperti pada tabel 4 .

Tabel 4. Penelitian terkait

\begin{tabular}{|c|c|c|c|c|}
\hline Peneliti & Judul & Metode & & Hasil \\
\hline Dwi Yuni Utami, 2015 & $\begin{array}{lr}\text { Perancangan } & \text { Sistem } \\
\text { Informasi } & \text { Jasa } \\
\text { Pengiriman } & \text { Barang } \\
\text { Antar } & \text { Pulau } \\
\text { Menggunakan } \\
\text { Waterfall pada PT. } \\
\text { Sinar Jaya Kusuma } \\
\text { Jakarta }\end{array}$ & -Waterfall & & $\begin{array}{lr}\text { Dengan } & \text { adanya } \\
\text { aplikasi } & \text { ini } \\
\text { perusahaan dapat } \\
\text { meningkatkan } \\
\text { pelayanan terhadap } \\
\text { pelanggan }\end{array}$ \\
\hline $\begin{array}{l}\text { Benni Triyono dkk, } \\
2017\end{array}$ & $\begin{array}{lr}\text { Rekayasa } & \text { Perangkat } \\
\text { Lunak } & \text { Sistem } \\
\text { Informasi } & \\
\text { Pengiriman } & \text { Dan } \\
\text { Penerimaan } & \text { Surat } \\
\text { Atau Paket Berbasis } \\
\text { Web (Studi } & \text { Kasus: } \\
\end{array}$ & $\begin{array}{l}\text {-System } \\
\text { Development } \\
\text { Cycle (SDLC) }\end{array}$ & Life & $\begin{array}{l}\text { Mampu } \\
\text { mempersingkat } \\
\text { waktu pengolahan } \\
\text { dan pencarian data } \\
\text { dalam Pengiriman } \\
\text { dan Penerimaan } \\
\text { Surat atau Paket. }\end{array}$ \\
\hline
\end{tabular}




\begin{tabular}{|c|c|c|c|}
\hline & $\begin{array}{l}\text { PT. Jaya } \quad \text { Trade } \\
\text { Indonesia) }\end{array}$ & & \\
\hline $\begin{array}{l}\text { Anik Setyaningsih } \\
\text { dkk, } 2020\end{array}$ & $\begin{array}{lr}\text { Rancang } & \text { Bangun } \\
\text { Sistem Informasi } \\
\text { Pengiriman } \\
\text { Berbasis Web (Studi } \\
\text { Kasus PT. Duta } \\
\text { Transindo Pratama } \\
\text { Surabaya) }\end{array}$ & - & $\begin{array}{l}\text { Sistem informasi } \\
\text { pengiriman barang } \\
\text { memudahkan } \\
\text { pelanggan } \\
\text { melakukan tracking } \\
\text { barang }\end{array}$ \\
\hline Siti Juwariyah dkk, 2021 & $\begin{array}{lr}\text { Rancang } & \text { Bangun } \\
\text { Aplikasi } & \text { Tracking } \\
\text { Paket Ekspedisi CV MK } \\
\text { Express }\end{array}$ & - & $\begin{array}{l}\text { Perusahaan berharap } \\
\text { dapat memperlancar } \\
\text { proses bisnis yang } \\
\text { dijalankan }\end{array}$ \\
\hline
\end{tabular}

Dari penelitian-penelitian sebelumnya masih belum menggunakan metode penelitian yang sudah berinteraksi langsung dengan user seperti menggunakan metode agile dan framework scrum sehingga hasil perangkat lunak yang dihasilkan pada penelitian ini bisa memuaskan pengguna softwarenya.

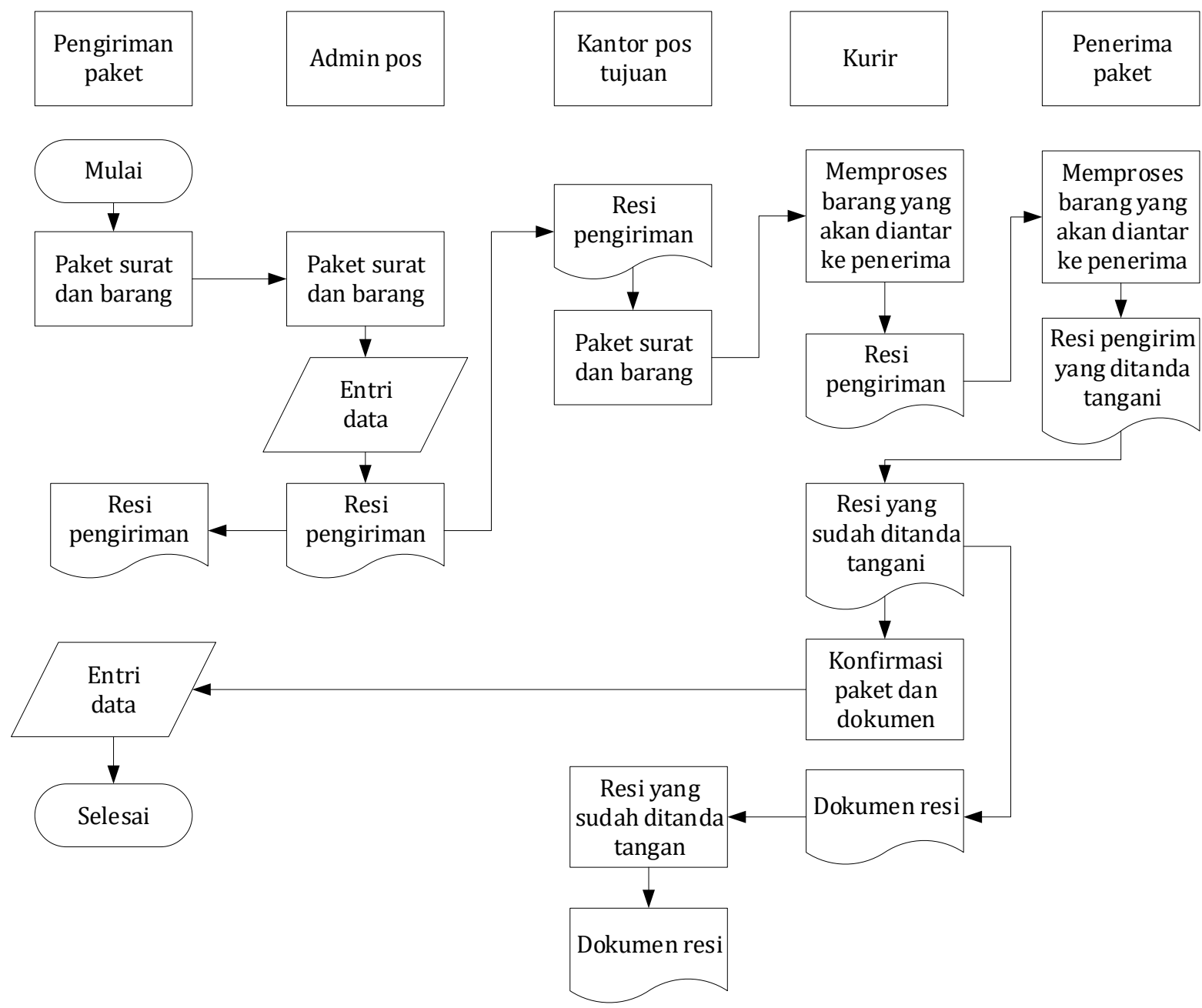

Gambar 3. Flowchart sistem usulan

\subsection{Analisis aplikasi penelusuran pengiriman paket}

Berdasarkan analisis yang dilakukan peneliti, sistem dan proses pengiriman barang yang sedang berjalan di PT. XYZ sudah berjalan dengan baik, namun pengolahan laporan data 
pengiriman masih memakan waktu yang lama karena kurir pengiriman harus kembali ke kantor PT. XYZ laporan pengiriman cabang atau update status paket. Oleh karena itu, untuk informasi mengenai laporan data pengiriman barang, sistem yang sedikit lebih lama perlu adanya peningkatan agar kedepannya lebih baik.

Berdasarkan flowchart pada sistem usulan bahwa tujuan perancangan ini memberikan gambaran alur proses pengiriman paket sampai tujuan atau penerima yang diharapkan pada sistem usulan ini[10], adapun kelebihan sistem yang diusulkan.

a. Penginputan laporan data pengiriman barang menjadi lebih cepat dan kurir pengantar barang tidak harus balik lagi ke kantor pos.

b. Jika pengiriman dengan jumlah yang banyak tidak membutuhkan waktu yang lama dalam laporan data pengiriman.

c. Memudahkan pembuatan laporan.

\subsection{Use case diagram}

Use case diagram pada gambar 4 menjelaskan kondisi dimana user dapat melacak posisi paket yang dikirim.

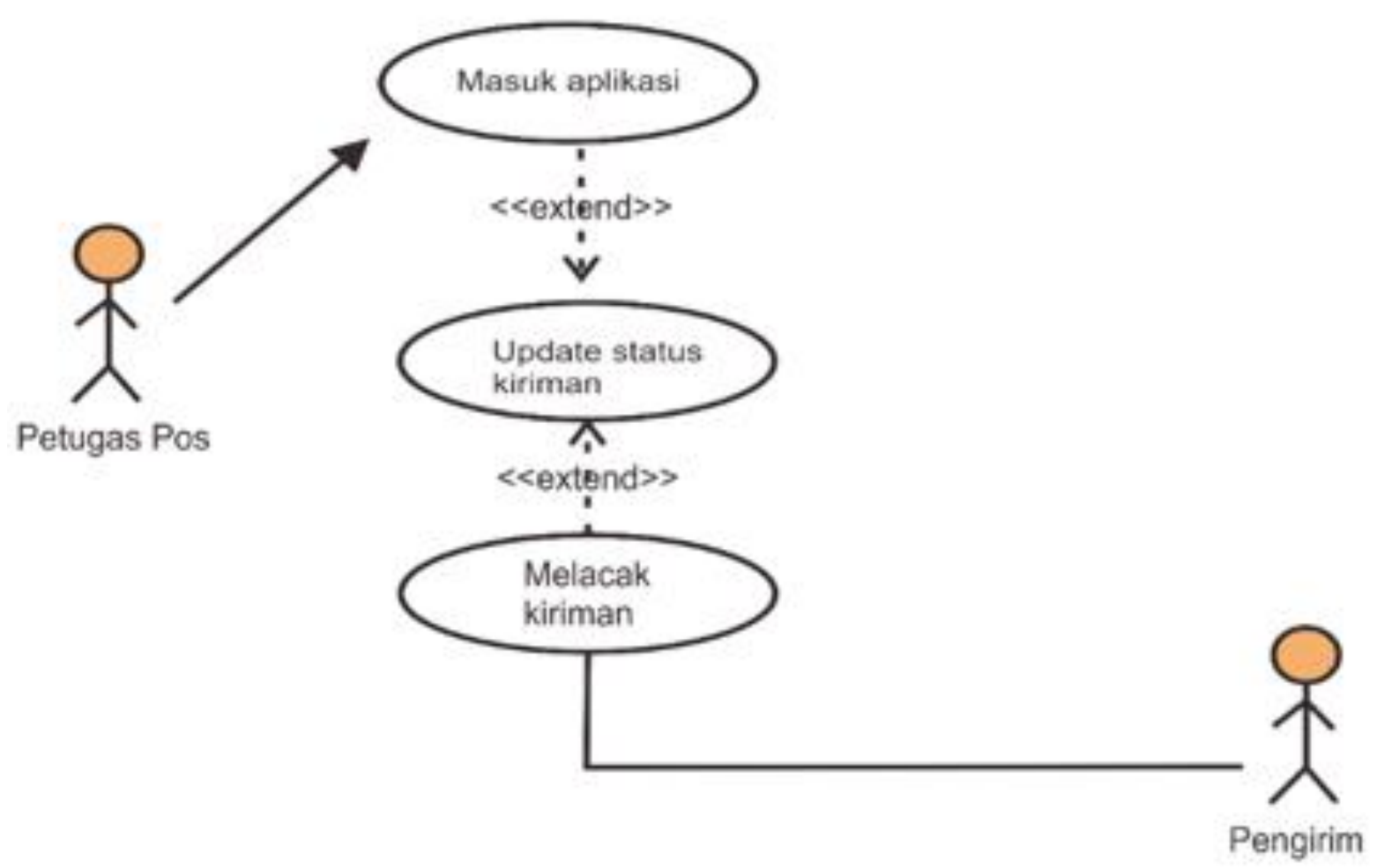

Gambar 4. Use case diagram

Keterangan gambar 2 Use case diagram pelacakan paket menggambarkan dari model fungi diagram UML yang mengilustrasikan use case sebagai persyaratan fungsi pada sistem aplikasi.

- Sistem dapat melakukan proses pelacakan kiriman paket

- Yang berperan dalam sistem pada use case sistem pelacakan paket yang terdiri dari 2 (dua) faktor yaitu petugas pos dan pengirim.

- Sistem use case pelacakan paket: use case login, update status kiriman, melacak kiriman dan logout. 


\subsubsection{Activity diagram lacak pengiriman paket.}

Pada activity diagram 5 menjelaskan bahwa pengirim dapat melakukan pelacakan kiriman pada halaman utama web. Pengirim memasukan nomor resi yang ingin dicari pengirim dan sistem menerima respon dari nomor resi.

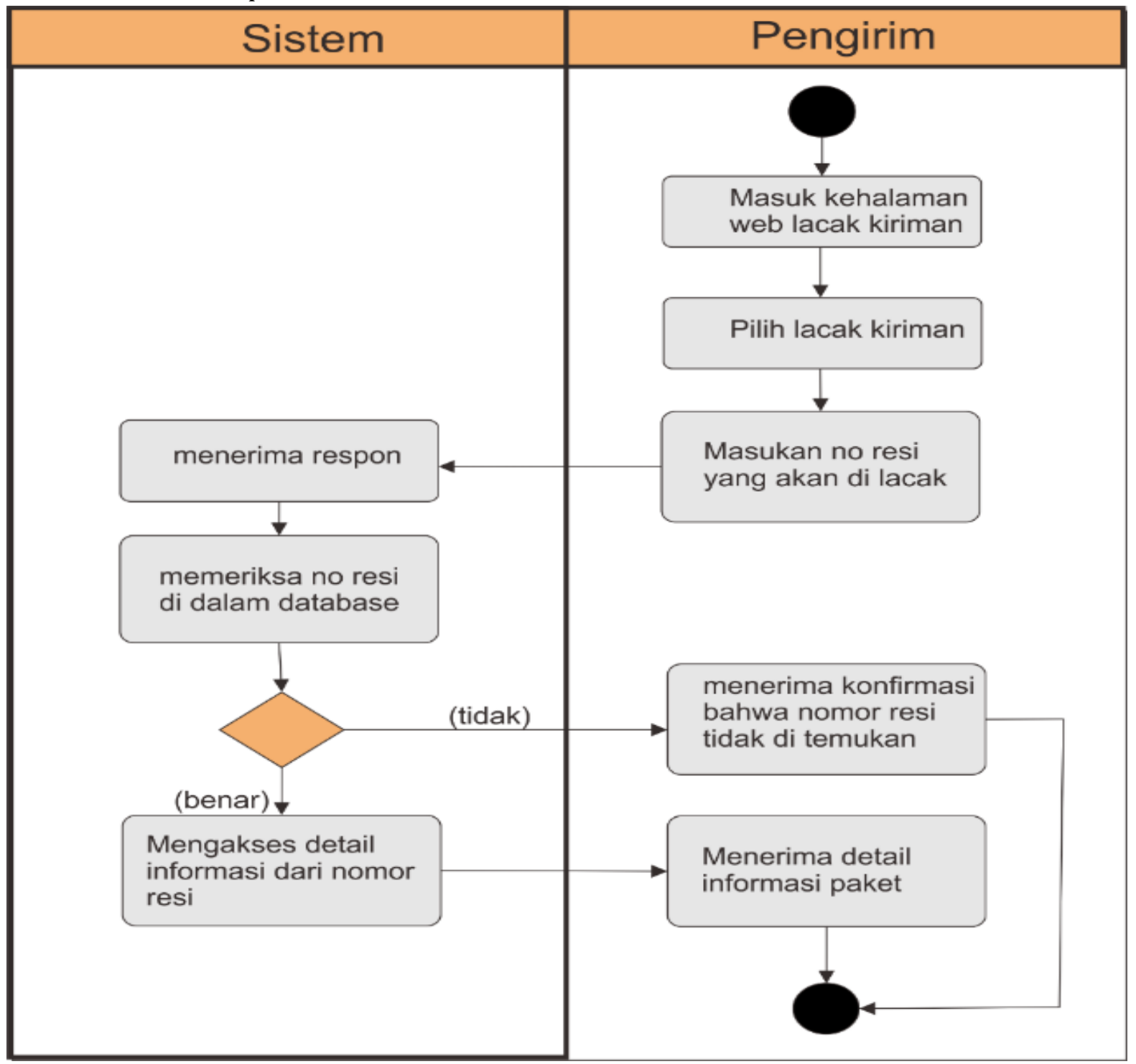

Gambar 5. Activity diagram lacak kiriman

Sistem memeriksa apakah nomor resi tersedia atau tidak. Jika tersedia maka akan menampilkan informasi detail status lacak kiriman, jika nomor resi tidak tersedia maka sistem akan mengirimkan pemberitahuan ke penerima bahwa nomor resi yang dicari tidak ditemukan.

\subsubsection{Sequence diagram update status kiriman}

Diagram ini menjelaskan user yang akan melakukan update status pengiriman. User mengakses halaman form update status pengiriman, kemudian user melakukan update status pengiriman paket dengan menginput nomor resi yang sudah berhasil diterima. Jika nomor resi yang dimasukkan benar maka akan membuka halaman konfirmasi kemudian petugas mengkonfirmasikan kiriman. Sedangkan jika nomor resi yang dimasukkan salah petugas diminta untuk memasukkan kembali nomor resi yang benar. 


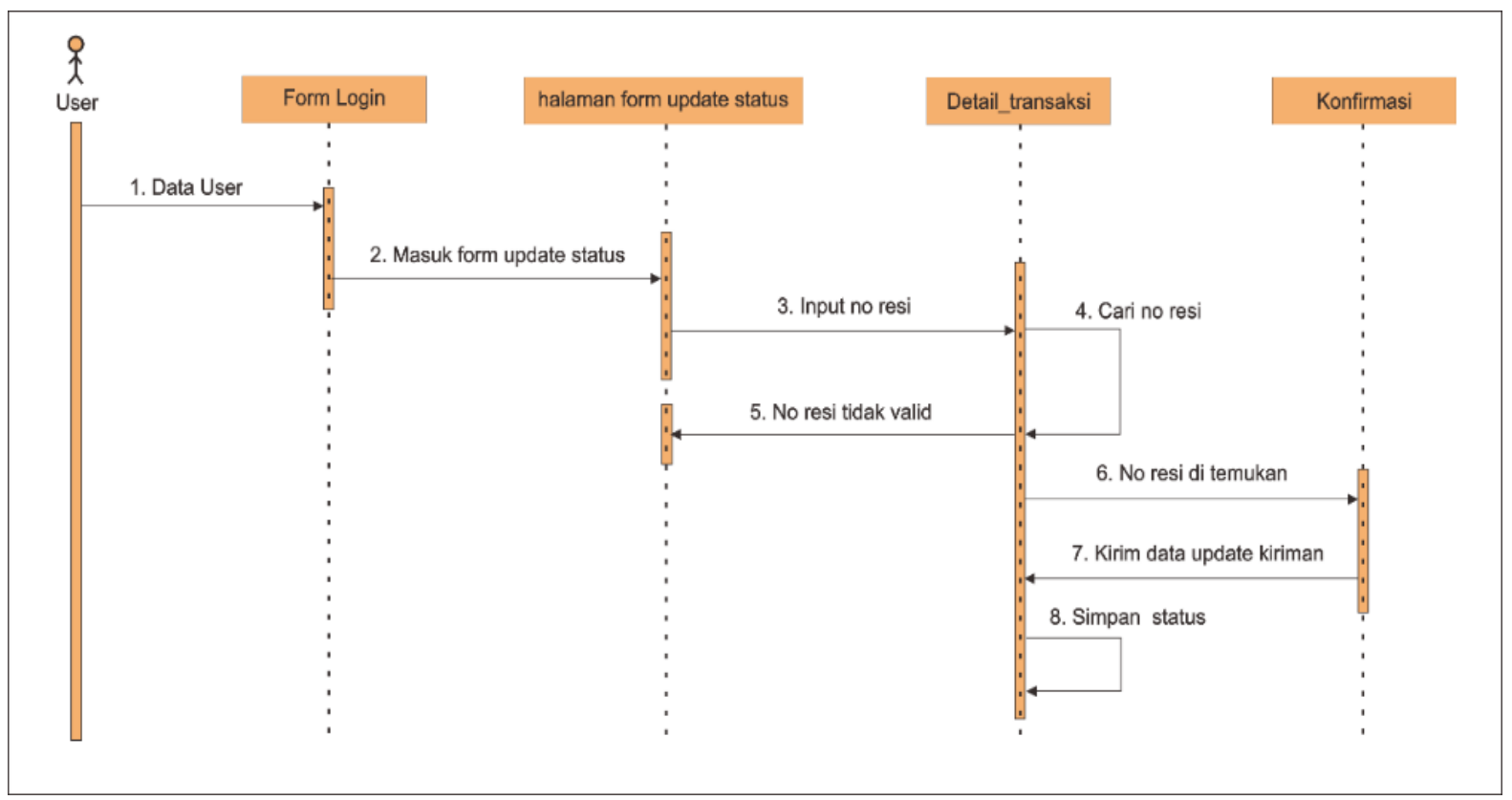

Gambar 6. Sequence diagram update status kiriman.

\subsection{Desain database}

Dalam merancang aplikasi sistem pelacakan berbasis web diperlukan database, yang dalam penelitian ini menggunakan server localhost. Adapun dalam perancangan aplikasi sistem pelacakan pengiriman paket dibentuk dengan tabel yaitu tabel pengirim, tabel detail paket, tabel penerima, tabel petugas, tabel master, daftar lokasi pos, dan tabel rincian transaksi, untuk menggambarkan relasinya.

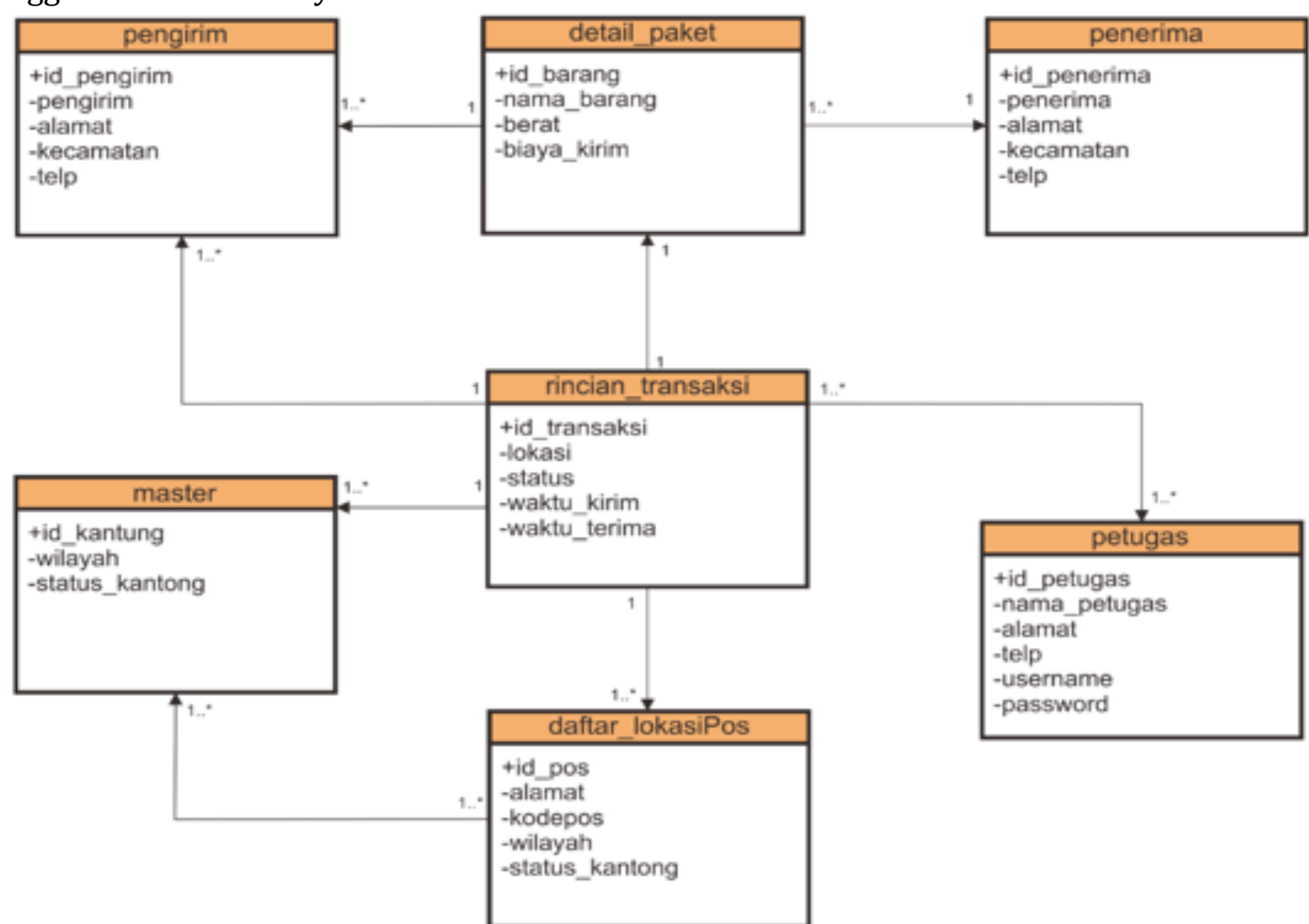

Gambar 7. Perancangan database 


\subsection{Antarmuka menu utama (Interface)}

Untuk memudahkan interaksi antara pengirim dan sistem aplikasi, maka sistem pelacakan paket dibuat desain interface dengan sistem yang terdiri dari antarmuka dengan pengguna yaitu login petugas, penerimaan pesanan, pelacakan pengiriman pesan, kurir dan akun user. Dimana antarmuka tersebut menggambarkan event atau kejadian pada komponen sistem pada suatu state ke state lainya.

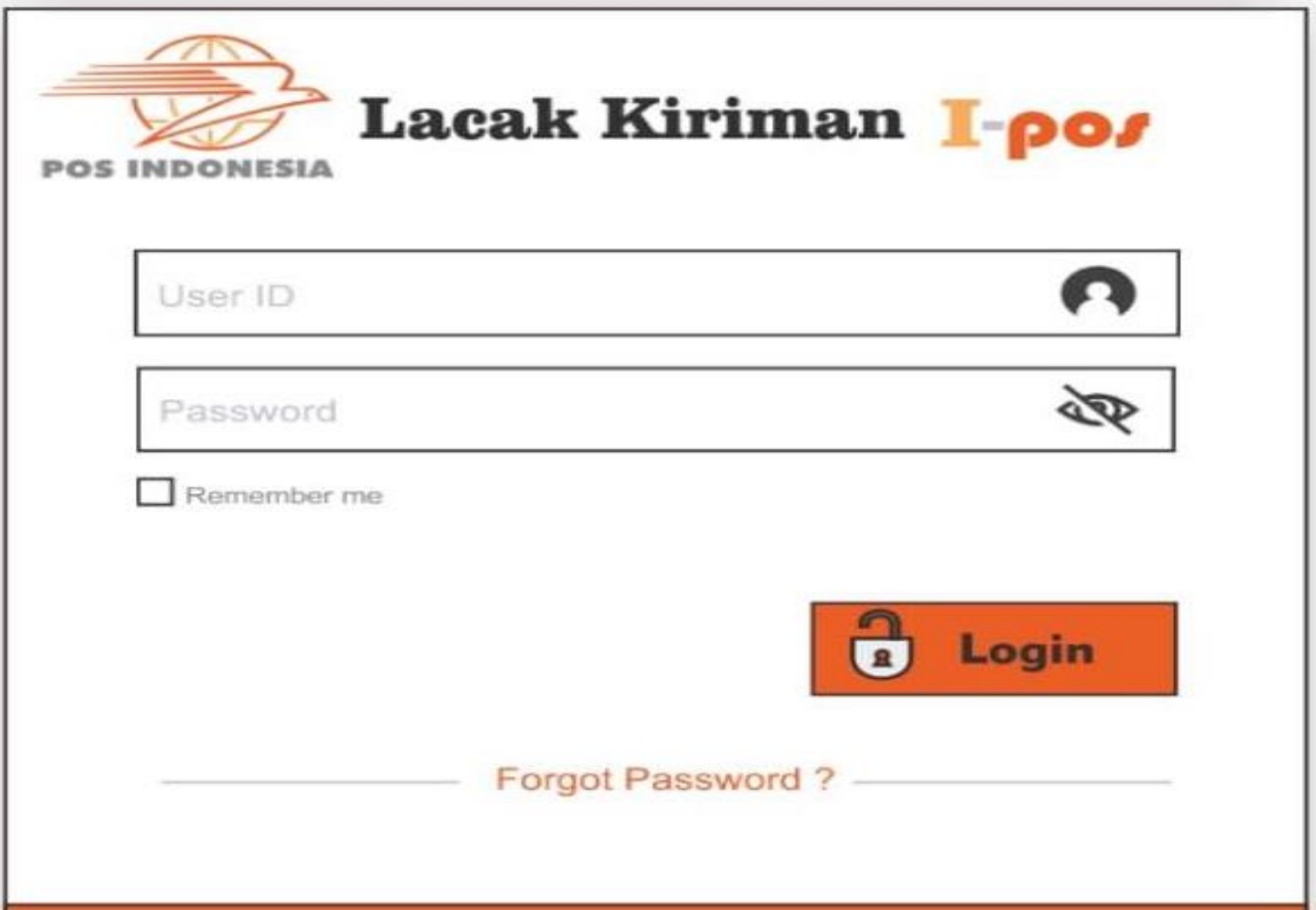

Gambar 8. Tampilan login.

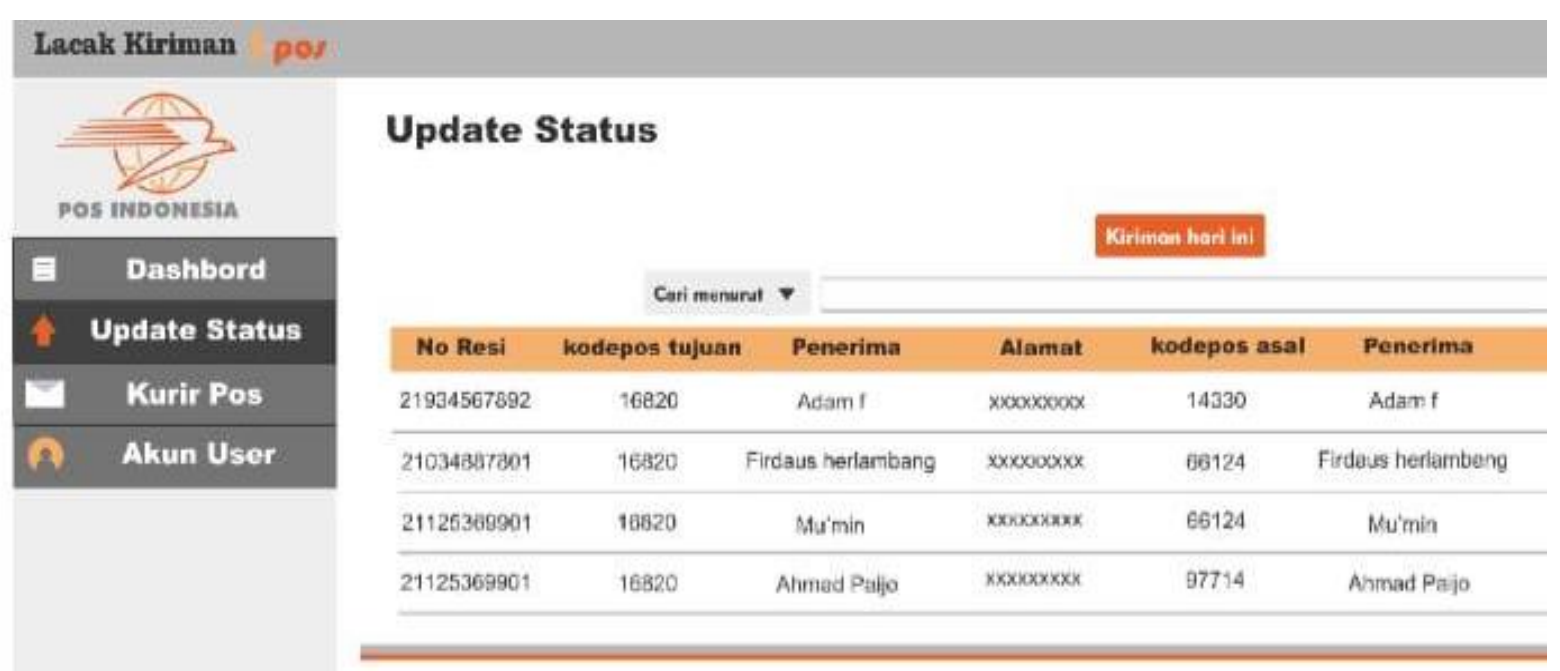

Gambar 9. Penerimaan pemesanan (status update) 


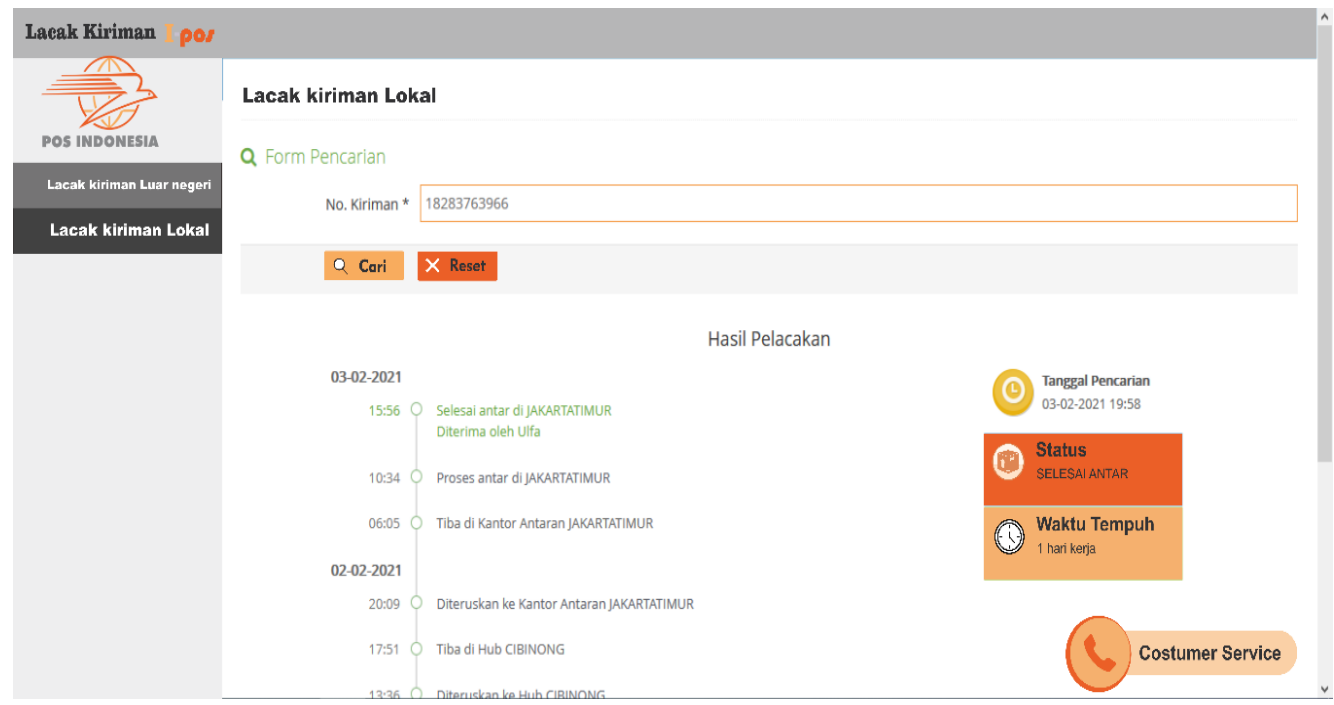

Gambar 10. Lacak pengiriman pesanan

\subsection{Pengujian sistem}

Untuk menguji performance perangkat lunak yang dirancang menggunakan metode ISO 9126. Dalam proses menguji dilakukan dengan cara mengajukan kuesioner model SUPR-Q pada sejumlah 10 responden dengan pertanyaan sebanyak 19 pertanyaan dan dengan dibagi menjadi 6 kategori berdasarkan standar ISO 9126. Dengan skala likert dengan rumus.

$$
\text { Nilai } S U P R-Q=\frac{\text { Jumlah Nilai Diperoleh }}{\text { Jumlah Nilai Maksimal }} x 100 \%
$$

Nilai Maksimal $=$ Jumlah Item $x$ Nilai Tertinggi $x$ Jumlah Responden

Menghasilkan performance dari liker pada functionality: 67.40\%, reliability: 71,66\%, usability: 76.25\%, efficiency: 68\%, maintainability: 76.50\% dan fortability: 75.33\%.

\section{SIMPULAN}

Setelah dilakukan perancangan dan implementasi aplikasi pelacakan pengiriman paket pos dengan menggunakan metode agile dengan framework scrum dan implementasi sistem pada server localhost dengan menggunakan bahasa pemrograman php dan framework codeigniter, maka dapat disimpulkan yaitu: (a) Aplikasi dapat membantu meringankan serta mempermudah proses kerja petugas pengantar barang sehingga lebih efisien waktu dalam pengolahan data dan pengiriman paket (b) Aplikasi sistem dapat mengurangi resiko yang dihadapi dalam pengolahan data pengiriman paket yang terkait masalah penelusuran posisi paket. (c) Sistem pelacakan pengiriman paket pada PT. Pos Indonesia (persero) cabang XYZ berbasis web ini agar penyampaian informasi kiriman dan pengolahan data update status kiriman oleh kurir (d) Hasil uji sistem menunjukan performance pada point usability sebesar $76.26 \%$, dimana pada penelusuran paket sistem sebelumnya membutuhkan waktu lama dengan adanya sistem pelacakan ini hanya membutuhkan waktu rata-rata 15 second (e) Aplikasi sistem pelacak paket ini dalam tahap pengembangan prototype dalam pengujiannya berjalan pada server localhost dan belum diimplementasikan pada hosting secara public.

\section{DAFTAR PUSTAKA}

[1] S. Fitria Putri, "Sistem Akuntansi Pengiriman Barang ( Menggunakan Microsoft Visual Basic 6.0 ) Pada Cv. Putera Sarana Utama," vol. 11, no. 1, pp. 90-97, 2017.

[2] A. S. Akbar, "Rancang Bangun Sistem Informasi Administrasi Hotel Dengan Metode 
Extreme Programming," J. Disprotek, vol. 8, no. 2, pp. 26-41, 2017.

[3] S. Hadji, M. Taufik, and S. Mulyono, "Implementasi Metode Scrum Pada Pengembangan Aplikasi Delivery Order Berbasis Website ( Studi Kasus Pada Rumah Makan Lombok Idjo Semarang )," Konf. Ilm. Mhs. Unissula 2, no. 2, pp. 32-43, 2019.

[4] N. Ruseno, "Implementasi Scrum pada Pengembangan Aplikasi Sistem Reservasi Online Menggunakan PHP,” Gerbang, vol. 9, no. 1, pp. 8-15, 2019.

[5] "Design thinking lean startup dan agile development." [Online]. Available: https://riyanthisianturi.com/design-thinking-lean-startup-dan-agile-development/. [Accessed: 11-Jun-2021].

[6] L. Listiyoko, A. Fahrudin, and A. Maksum, "Perancangan Aplikasi Cafe Untuk Efisiensi Order Menggunakan Metode Agile," Semin. Nas. Teknol. Inf., pp. 113-120, 2017.

[7] Prabowo D, Website E-Commerce Menggunakan Model View Controller (MVC) Dengan Framework Codeigniter Studi Kasus: Toko Miniatur., Data Manaj. 2015.

[8] C. Ram Mohan Reddy, "General Methodology for developing UML models from UI," Int. J. Web Serv. Comput., vol. 2, no. 4, pp. 107-16, 2011.

[9] B. Padmanabhan, "Unified Modeling Language (UML) Overview," Princ. Softw. Eng., pp. 120, 2012.

[10] Haviluddin, “Memahami Penggunaan UML ( Unified Modelling Language )," Memahami Pengguna. UML (Unified Model. Lang., vol. 6, no. 1, pp. 1-15, 2011. 